\title{
Comparative Effects of Animal and Vegetable Fats on Lipid Profile and Patho-physiological Changes in Mice
}

\author{
S. Akter ${ }^{1 *}$, M. A. Miah", M. A. H. N. A. Khan ${ }^{2}$, and M. K. Islam ${ }^{1}$ \\ ${ }^{1}$ Department of Physiology, Faculty of Veterinary Science, Bangladesh Agricultural University, \\ Mymensingh-2202, Bangladesh \\ ${ }^{2}$ Department of Pathology, Faculty of Veterinary Science, Bangladesh Agricultural University, \\ Mymensingh-2202, Bangladesh
}

Received 22 September 2012, accepted in revised form 5 April 2013

\begin{abstract}
Dietary intake of high amounts of animal fats can cause hypercholesterolemia whereas plant fat like soybean oil reduces serum cholesterol and lipoproteins in mice. The effects of animal fat (butter) and plant fat (soybean oil) fortified diet on lipid profile (serum total cholesterol, low density lipoprotein-cholesterol (LDL-C), high density lipoprotein cholesterol (HDL-C), and triglycerides), body weight, blood glucose and on tissue texture were investigated in mice. 30 Swiss albino mice were divided equally into three groups. Mice were fed a normal diet (untreated control), a high-fat diet (5\% butter) (butter group) and an unsaturated fat diet (5\% soybean oil) (soybean oil group) for 90 days. Mice of butter group showed significantly increased level of total cholesterol, LDL-C and triglycerides and decreased level of HDL-C in the serum but not found in mice of soybean fed diet group. Body weight and blood glucose were also markedly elevated in mice fed only butter enriched diet. Histological analysis of liver at the end of 90 days showed increased fat deposition in the mice fed with butter diet than those of control diet and plant fat diet group. Mice fed with butter showed an elevation of lipid levels and developed fatty changes in liver.
\end{abstract}

Keywords: Butter; Soybean oil; Lipid profile; Fatty change; Mice

(C) 2013 JSR Publications. ISSN: 2070-0237 (Print); 2070-0245 (Online). All rights reserved. doi: http://dx.doi.org/10.3329/jsr.v5i2.11909 $\quad$ J. Sci. Res. 5 (2), 353-361 (2013)

\section{Introduction}

Hypercholesterolemia is a lipoprotein metabolic disorder characterized by high serum low density lipoprotein and blood cholesterol and one of the most important risk factors for the development of cardiovascular diseases (CVD) and lipid abnormalities [1-3]. Clinical trials have demonstrated that intensive reduction of plasma LDL-C levels could reverse atherosclerosis and decrease the incidence of CVDs [4, 5]. Continuous ingestion of high

*Corresponding author: sharmin.akter@bau.edu.bd 
amounts of saturated fats and cholesterol are directly related to hypercholesterolemia and susceptibility to atherosclerosis [6]. Generally, high-fat diets, high sucrose/fructose diets, diets high in saturated fats and restricted in certain essential nutrients, like choline and methionine, have been shown to cause obesity and fatty livers in a number of different strains and species of rodents. High-fat western diets induce extreme hypercholesterolemia and also lead to concomitant features of the metabolic syndrome, such as weight gain, decreased HDL levels, obesity, hypertriglyceridemia hyperinsulinemia, and insulin resistance. On the other hand, soybean oil reduced serum cholesterol and lipoproteins in different aged mice fed on hypercholesterolemic diets [7]. This is because of soybean oil is rich in UNSFAs, especially PUSFAs. Polyunsaturated fats stimulate the catabolic rate of LDL-cholesterol, thus resulting in the reduction of serum LDL-cholesterol. It also improves serum lipid profile [8]. Soybean oil lowers the serum cholesterol and low density lipoprotein-cholesterol levels by 41 and $50 \%$, respectively [9]. Ingestion of soybean beta-conglycinin suppreses the increase in body fat ratio in individuals with a high baseline body fat ratio and reduced relatively high serum levels of lipids [10]. Lipid structure, composition, configuration, in addition to excessive fat and cholesterol consumption are also believed to affect the lipid profile in the plasma [11]. Hypercholesterolemic animals are useful models for studies on cholesterol homeostasis, and drug trials to better understand the relationship between disorders in cholesterol metabolism, atherogenesis as well as possible treatments for the reduction of circulatory cholesterol levels [12, 13].Therefore, the present study was aimed to investigate the effect of the inclusion of butter and soybean oil in the diet on hypercholesterolemia and fatty changes in the liver in mice. We found that mice fed with a high-fat diet (butter) showed an elevation of lipid levels and developed fatty change but not by soybean oil.

\section{Materials and methods}

\subsection{Animals}

Two months old 30 male Swiss Albino mice (Mus musculus) with an average body weight of 18-25g were obtained from ICDDR,B, Dhaka, Bangladesh. Before being used in the experiment, mice were adapted for 3 days in order for them to get used to the environment. All mice were maintained in the animal care facilities according to university animal care and use guidelines.

\subsection{Experimental protocol and diets}

After arrival, animals were allowed free access to a basal diet of commercial rodent ration and water for 3 days to allow adaptation to the environment. Baseline values of serum total cholesterol were measured. Further, these basal serum total cholesterol values were used to assign animals into 3 groups. The control group continued to be fed the normal 
rodent diet. The other groups $(n=10)$ were fed with $5 \%$ butter and $5 \%$ soybean oil with free access to water and food for 90 days. Body weight was measured at 45 and 90 days. Blood samples were collected at 45 days of experiments from food-deprived mice (14 hours) anesthetized with $3 \mu \mathrm{L}$ of $5 \mathrm{mg} / \mathrm{mL}$ acepromazine from the lateral saphenous vein using a sterile 23 gauge needle. At the end of the experimental period (90 days), the mice were euthanized by carbon dioxide asphyxiation and blood was withdrawn by cardiac puncture using a 22 gauge needle and a $5 \mathrm{~mL}$ syringe. Cardiac blood was transferred into serum separator tubes and allowed to clot prior to placement on ice.

\subsection{Serum cholesterol, triglyceride and glucose measurements}

The blood was allowed to clot at $23^{\circ} \mathrm{C}$ for 30 minutes and subsequently placed at $4^{\circ} \mathrm{C}$ until centrifugation. Serum was separated by low-speed centrifugation at $2000 \mathrm{~g}$ for 20 min at $4{ }^{\circ} \mathrm{C}$ temperature. Serum was frozen at $-85^{\circ} \mathrm{C}$ until further analysis. Serum total cholesterol, HDL cholesterol, triglycerides, and glucose were measured on the Hitachi 911 automated analyzer using reagent kits supplied by Roche Diagnostics (Laval, QC, Canada). The precision performance of these assays was within the manufacturer's specifications. LDL cholesterol was calculated by the Friedewald equation [14].

\subsection{Histology}

The whole liver was excised from each animal, immersed in chilled phosphate-buffered saline and blotted dry. A $4 \mathrm{~mm}$ section of the liver was placed into a histological cassette. The cassette containing the liver section of each animal was individually immersed in a $10 \%(\mathrm{v} / \mathrm{v})$ buffered formalin phosphate solution for fixing and subsequent staining. The formalin-fixed, paraffin-embedded tissue samples were ultra sectioned (4-5 $\mu \mathrm{m}$ thickness), stained with hematoxylin and eosin and examined under a light microscope.

\subsection{Statistical analysis}

All data were expressed as mean $\pm \mathrm{SD}$, and differences among the groups of animals were compared using one-way ANOVA with post-hoc Duncans test. Statistical significance was set at $p<0.05$. Statistical analysis was performed using SPSS software version 17 (SPSS Inc., Chicago, IL, USA).

\section{Results}

The animals consumed the daily rations satisfactorily and grew well during the study. Changes in body weight of animals at 45 days interval in each group were presented in Fig. 1. At the end of the feeding period, mice fed with butter had significantly higher $(p<0.01)$ body weight than normal diet fed mice after 90 days of experiment. We found mice fed with soybean oil diet showed significantly lower growth response similar with normal fed rats. 
Table 1. Effect of butter and soybean oil on body weight (g) and blood glucose (mmol/L) in mice.

\begin{tabular}{lcccc}
\hline Groups & \multicolumn{2}{c}{ Body weight } & \multicolumn{2}{c}{ Blood glucose } \\
\cline { 2 - 5 } & Day 45 & Day 90 & Day 45 & Day 90 \\
\hline Untreated control & $26.25 \pm 1.16^{\mathrm{b}}$ & $32.31 \pm 2.76^{\mathrm{b}}$ & $4.57 \pm 1.04^{\mathrm{b}}$ & $4.83 \pm 0.66^{\mathrm{b}}$ \\
Butter & $29.50 \pm 1.92^{\mathrm{a}}$ & $37.81 \pm 1.85^{\mathrm{a}}$ & $5.75 \pm 0.52^{\mathrm{a}}$ & $7.83 \pm 2.19^{\mathrm{a}}$ \\
Soybean oil & $26.25 \pm 1.03^{\mathrm{b}}$ & $32.98 \pm 2.73^{\mathrm{b}}$ & $4.57 \pm 0.58^{\mathrm{b}}$ & $4.87 \pm 0.64^{\mathrm{b}}$ \\
\hline
\end{tabular}

Data are shown as mean \pm SD of $n=10$ samples per group.

Values in the same column with different superscript letters are significantly different, $p<0.01$.

Table 2. Effect of butter and soybean oil on lipid profile (mg/dl) in mice.

\begin{tabular}{ccccccccc}
\hline \multirow{2}{*}{ Groups } & \multicolumn{2}{c}{ Total cholesterol } & \multicolumn{2}{c}{ Triglycerides } & \multicolumn{2}{c}{ HDL-C } & \multicolumn{2}{c}{ LDL-C } \\
\cline { 2 - 9 } & Day 45 & Day 90 & Day 45 & Day 90 & Day 45 & Day 90 & Day 45 & Day 90 \\
\hline Untreated & 68.12 & 73.75 & 89.50 & 91.62 & 35.25 & 50.25 & 34.50 & 35.12 \\
control & $\pm 2.03^{\mathrm{b}}$ & $\pm 3.53^{\mathrm{b}}$ & $\pm 1.30^{\mathrm{b}}$ & $\pm 2.19^{\mathrm{b}}$ & $\pm 3.37^{\mathrm{a}}$ & $\pm 4.16^{\mathrm{a}}$ & $\pm 0.92^{\mathrm{b}}$ & $\pm 1.24^{\mathrm{b}}$ \\
& 121.87 & 180.00 & 116.87 & 87.50 & 18.62 & 33.12 & 87.75 & 37.00 \\
Butter & $\pm 10.94^{\mathrm{a}}$ & $\pm 6.54^{\mathrm{a}}$ & $\pm 9.97^{\mathrm{a}}$ & $\pm 1.19^{\mathrm{b}}$ & $\pm 2.26^{\mathrm{b}}$ & $\pm 3.22^{\mathrm{a}}$ & $\pm 4.33^{\mathrm{a}}$ & $\pm 0.75^{\mathrm{b}}$ \\
& 66.50 & 72.75 & 151.87 & 90.87 & 21.12 & 48.62 & 120.00 & 33.50 \\
Soybean & $61.55^{\mathrm{b}}$ & $\pm 3.81^{\mathrm{b}}$ & $\pm 16.24^{\mathrm{a}}$ & $\pm 3.83^{\mathrm{b}}$ & $\pm 2.64^{\mathrm{b}}$ & $\pm 6.63^{\mathrm{a}}$ & $\pm 10.35^{\mathrm{a}}$ & $\pm 1.30^{\mathrm{b}}$ \\
\hline
\end{tabular}

Data are shown as mean \pm SD of $n=10$ samples per group..

Values in the same column with different superscript letters are significantly different, $p<0.01$.

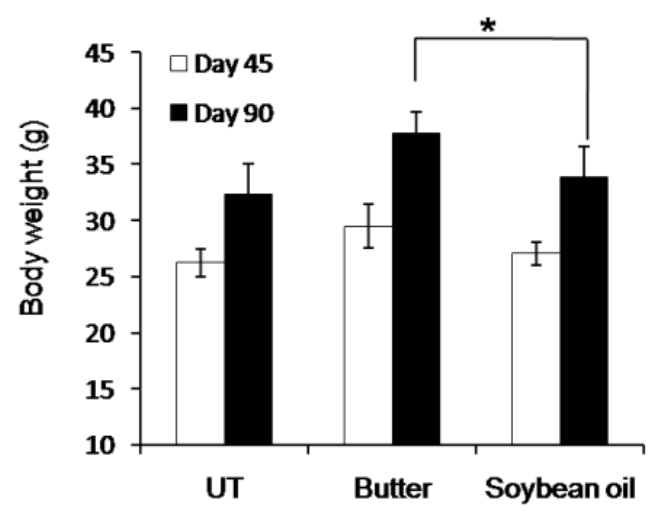

Fig. 1. Effect of butter and soybean oil on body weight (g) in mice. Mice were fed with butter or soybean oil acid for the 90 days of experimental period. At the end, body weights were measured at 45 and 90 days and values were represented as Mean \pm SD of 10 mice of each group. UT-untreated control. ${ }^{* *} p<0.01$.

Blood glucose was observed to be significantly higher $(p<0.01)$ in the butter fed animals compared with the soybean oil-fed and control (Fig. 2). The soybean oil-fed mice even had significantly lower blood glucose levels compared to the control. 


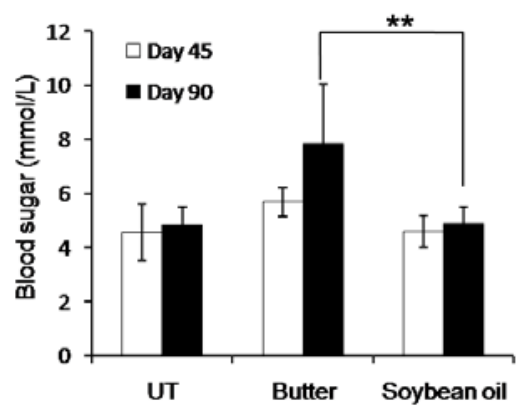

Fig. 2. Effect of butter and soybean oil on blood sugar in mice. Mice were fed with butter or soybean oil acid for the 90 days of experimental period. Blood was collected at 45 days and 90 days and sugar level of each group was determined using Hitachi 911 automated analyzer according to company instruction and values were represented as mean \pm SD of 10 mice. ${ }^{* *} p<0.01$.

Measurement of serum total cholesterol, serum triglyceride and serum LDL concentrations observed that the butter fed mice had significantly higher serum cholesterol and triglyceride levels compared with the soybean oil-fed mice and control after 45 and 90 days of experiments (Fig. 3) However, serum HDL level had lower value in butter fed mice which was significantly different $(p<0.01)$.
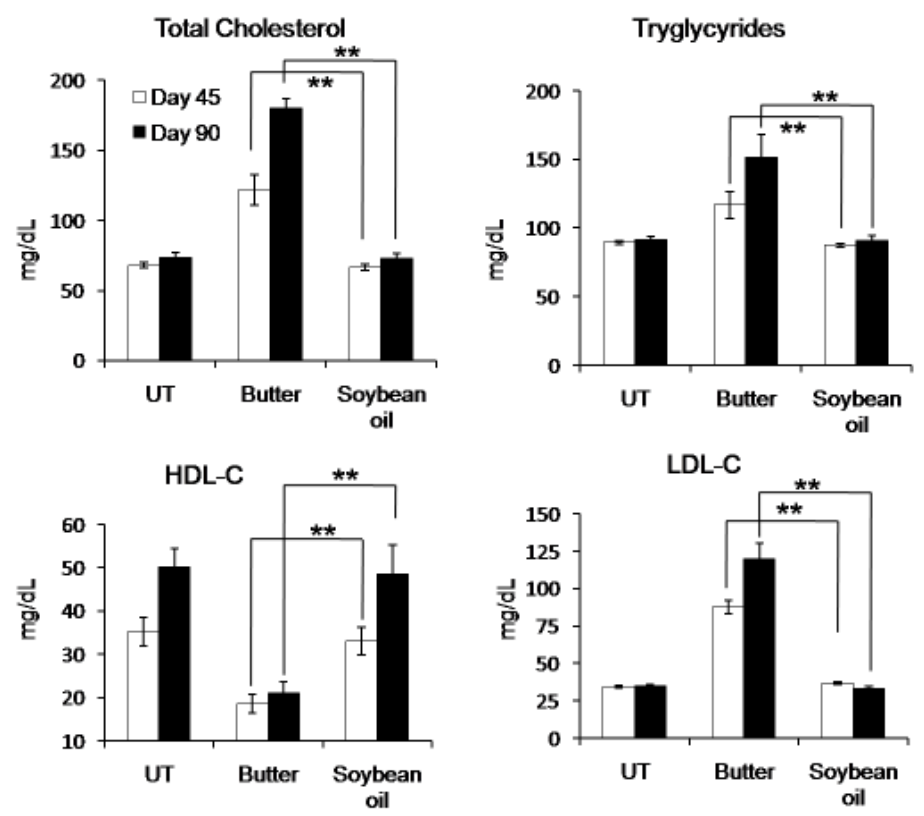

Fig. 3. Effect of butter and soybean oil on blood lipid profile in mice. Mice were fed with butter or soybean oil acid for the 90 days of experimental period. Blood was collected at 45 days and 90 days and Total cholesterol, triglycerides, HDL-C and LDL-C of each group was determined using Hitachi 911 automated analyzer according to company instruction and values were represented as mean $\pm \mathrm{SD}$ of 10 mice. ${ }^{* *} p<0.01$. 
Histopathological analysis of liver samples through H\&E and staining show marked differences between the groups studied. Hematoxylin and eosin staining demonstrated elevated amounts of fat deposits in liver tissue from animals fed on butter compared with the normal diet and soybean oil fed diet (Fig. 4). Macro-vesicular deposition of fat and hepatocellular ballooning was observed in mice fed on butter (Fig. 4) but not found in liver of soybean oil fed mice. Histological analysis confirms the development of fatty change in butter fed groups only. However, there were no signs of fibrosis.
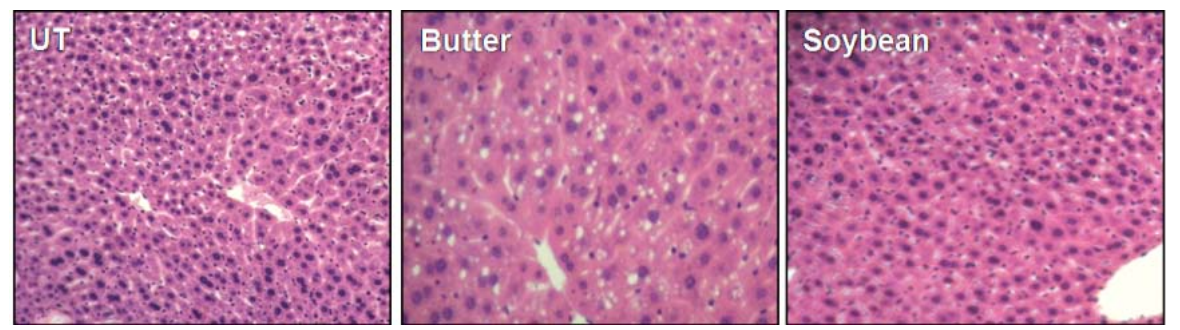

Fig. 4. Histopathological changes of liver of mice. Mice were fed with butter or soybean oil both for the indicated peroid. Liver of each group were collected and processed for histo-chemistry. Photographs were taken under microscope (LABOMED) at 400X magnification. Notify that only in butter fed mice, hepatocytes are filled with microvascular and macro vesicular fat deposits, leaving the nuclei in a central position, and the hepatocytes have assumed a very foamy appearance. UTuntreated control.

\section{Discussion}

We have investigated effect of either animal or plant fat on lipid profile and liver changes in mice in relation to cardiovascular diseases. We used butter as animal fat and soybean oil as plant fat sources. Serological and histo-pathological changes in mice fed on hyperlipidemic diets varying in saturated and unsaturated fatty acids in comparison with a normal diet were evaluated during this study. Our results suggest that swiss albino mice are a potential model for diet-induced hyperlipidemia and non-alcoholic fatty liver disease. The findings with regard to addition of butter agreed with previous studies founded that diets high in saturated fat and cholesterol facilitate weight gain, a predisposing factor of obesity in various animal model [15]. Saturated fatty acids increase total plasma cholesterol, especially LDL-C [16]. Dietary lipids participate actively in the development of atherosclerosis which is characterized by elevated triglyceride levels in blood plasma [17], these results agreed with our findings. With regard to the effect of butter our findings agreed with another researcher [18], who reported that butter was found to produce a depression in HDL-C and an elevation of VLDL and low LDL-C in the atherosclerosis-susceptible mice. It has been reported that the relative content of saturated and poly unsaturated fatty acids (PUFA) in the diet affects plasma level of cholesterol [19]. Polyunsaturated Fatty Fcids (PUFA) are well known for 
their anti-inflammatory and insulin-sensitizing properties, and also cause hypolipidemia [20]. Although metabolic studies have shown that consumption of n-6 PUFA lowers circulating cholesterol level [2], Increase in LDL-C has been pointed out as one of the risk factors for the development of atherosclerosis and related cardiovascular diseases [21]. Hence, the result obtained in this study indicated that the dietetic model is suitable for studies in atherogenesis. Our results with regard to addition of soybean oil to the diet, agreed with previous studies founded that soybean oil reduced serum cholesterol and lipoproteins in different aged mice fed on hypercholesterolemic diets [7] and it improves serum lipid profile [8]. These results may be possibly explains on the basis that soybean oil is rich in UNSFAs, especially PUSFAs. Polyunsaturated fats stimulate the catabolic rate of LDL-cholesterol, thus resulting in the reduction of serum LDL-cholesterol [7]. Concerning, the effect of butter on serum lipid profile, our findings agreed with previous reported showing that, butter produced a significant rise in serum total cholesterol (TC) in normocholesterolemic women [22] and increased serum TC, LDL-C and decreased HDLC [23]. These results may be explained on basis that the high SFAs and low PUSFAs contents in butter, which is an important contributing factor to raising serum cholesterol level. The hyperlipidemic effects of the diets were visibly demonstrated in the increased body weight and lipid profile of serological samples from mice fed on butter. The animals showed hyperglycemia which is commonly associated with metabolic syndrome. In addition, histopathological analysis revealed extensive diet-induced hepatocellular fat deposition and ballooning in the liver samples from the mice, while the control and soybean oil fed mice had normal liver histology. However, the spectrum of conditions characterized by fatty change in the liver had not progressed to necrosis, fibrosis, or inflammation. In comparison with the normal diet, the hyperlipidemic diets were also associated with elevated serum total cholesterol levels, decreased HDL cholesterol, and hyperglycemia and hypertriglyceridemia, thereby confirming the induction of metabolic syndrome and nonalcoholic fatty liver in the mice. In liver, glycogen synthesis and concentration were higher in rats receiving hypercaloricsaturated fat and normocaloricsaturated fat [24]. Thus, this study opens up new approaches to investigate further the long-term effects of butter on the animal model. This study concluded that dietary intake of vegetable oils is more beneficial than animal fats (butter) as they improve lipid profile in mice. LDL-cholesterol was significantly reduced on the soybean oil-diet compared to the butter-diet [25]. It has been previously shown that constituents of soybean oil, such as $\alpha$-linolenic acid, are capable of reducing cholesterol in hypercholesterolaemic patients [26]. Soybean oil, the vehicle of $\alpha$-LA in this study, had a significant effect in lipid profile with a significant reduction of plasma triglycerides, cholesterol and phospholipid levels. $\alpha$-LA and soybean oil significantly reduced both total and non-HDL serum cholesterol and triglycerides induced by atherogenic diet [27].

In agreement with this work, several studies have reported a lack of effect of soybean oil in endothelial function in humans [28]. It is known that fatty acid composition of food is more associated with variations in the plasma total cholesterol level. 


\section{Conclusion}

This study concluded that dietary intake of vegetable oils, which are rich in unsaturated fatty acids, reduces the risk of atherosclerosis and coronary heart disease, while saturated fatty acids have the opposite effect.

\section{Acknowledgements}

We thank ICDDR, B for providing mice in due time. This work was supported by the National Science and Technology (NST) funded by the Ministry of Science and Technology (MOS), Bangladesh.

\section{References}

1. S. L. Matos, H. Paula, M. L. Pedrosa, R. C. Santos, E. L. Oliveira, Jr. D. A. Chianca, and M.E. Silva, Brazilian Archives Biol. Technol. 48, 203 (2005).

2. H. D. Ramachandran, K. Narasimhamurthy, and P.L. Raina, Nutr. Res. 23, 245 (2003). http://dx.doi.org/10.1016/S0271-5317(02)00517-1

3. K. Rerkasem, P. J. Gallagher, R. F. Grimble, P. C. Calder and C.P. Shearman, Vasc Health Risk Manag. 4, 1259 (2008).

4. A. J. Brown and W. Jessup, Atherosclerosis. 142, 1 (1999). http://dx.doi.org/10.1016/S0021-9150(98)00196-8

5. T. Ichihashi, M. Izawa, K. Miyata, T. Mizui, K. Hirano, and Y. Takagishi, J. Pharmacol. Exper.Therapeutics (JPET) 284, 43 (1998).

6. M. Asashina, M. Sato and K. Imaizumi, J. Lipid. Res. 46, 2289 (2005). http://dx.doi.org/10.1194/jlr.M500257-JLR200

7. Y. Choi, C. Ahn, H. Rhee, M. Choe, C. Kim and J. Kim, Bioscui. Biotech. Biochem. 57, 65 (1993). http://dx.doi.org/10.1271/bbb.57.65

8. M. A. Ramadan, M. A. Amer, and A. E. Awad, Eur. Food Res. Technol. 227, 1173 (2008). http://dx.doi.org/10.1007/s00217-008-0833-y

9. W. Gilbert, V. Gadang, A. Proctor, V. Jain, and L. Devareddy, Lipids. 46, 961 (2011). http://dx.doi.org/10.1007/s11745-011-3585-6

10. T. Baba , A. Ueda , M. Kohno, K. Fukui , C. Miyazaki , M. Hirotsuka, and M. Ishinaga, J. Nutr. Sci Vitaminol (Tokyo) 50, 26 (2004). http://dx.doi.org/10.3177/jnsv.50.26

11. M. A. Zulet, A. Barber, H. Garcin, P. Higueret, and J. A. Martinez, J. Am. Coll. Nutr. 18, 36 (1999).

12. M. A. Pellizon, Brief scientific literature review (2008). Retrieved from www.researchdiets.com/pdf/product/atherosclerosis 3\%page.pdf

13. M. J. Jang and M. H. Wang, Food Biotechnol. 23, 74 (2009). http://dx.doi.org/10.1080/08905430802672020

14. W. T. Friedewald, R. I. Levy, and D. S. Fredrickson, Clin. Chem. 18, 499 (1972).

15. L. K. Sarna, N. Wu, P. Wang, S. Y. Hwang, Y. L. Siow, and O. Karmin, Can. J. of Physiol. Pharmacol. 90, 155 (2012). http://dx.doi.org/10.1139/y11-124

16. L. Ohlsson, Food Nutr. Res. 54, 10 (2010).

17. B. Bałasińska and A. Mazur, Postepy Hig. Med. Dosw, (Online), 58, 176 (2004).

18. P. M. Nishina, J. Verstuyft, and B. Paigen, J. Lipid Res. 31, 859 (1990).

19. H. Ohtani, K. Hayashi, Y. Hirata, S. Dojo, K. Nakashima, E. Nishio, H. Kurushima, M. Saeki, and G. Kajiyama, J. Lipid Res. 31, 1413 (1990).

20. J. M. Tishinsky, Appl. Physiol. Nutr. Metab. 38, 361 (2013). http://dx.doi.org/10.1139/apnm-2012-0447 
21. G. S. Getz and C. A. Reardon, Arteriosclerosis Thromb. Vasc. Biol. 26, 242 (2006). http://dx.doi.org/10.1161/01.ATV.0000201071.49029.17

22. G. M. Wardlaw and J. T. Snook, Am. J. Clin. Nutr. 51, 815 (1990).

23. A. H. Lichtenstein, L. M. Ausman, W. Carrasco, J. L. Jenner, J. M. Ordovas, and E. J. Schaefer, Arterioscler Thromb. Vasc. Biol. 13, 154 (1993). http://dx.doi.org/10.1161/01.ATV.13.2.154

24. A. L. Hoefel, F. Hansen, P. D. Rosa, A. M. Assis, S. L. Silveira, C. C. Denardin, L. Pettenuzzo, P. R. Augusti, S. Somacal, T. Emanuelli, M. L. Perry, C. M. Wannmacher, Cell Biochem. Funct. 29, 569 (2011). http://dx.doi.org/10.1002/cbf.1789

25. K. Almendingen, O. Jordal, P. Kierulf, B. Sandstad, and J. I. Pedersen, J. Lipid Res. 36, 1370 (1995).

26. A. H. Lichtenstein, N. R. Matthan, S. M. Jalbert, N. A. Resteghini, E. J. Schaefer, and L. M. Ausman, Am. J. Clin. Nutr. 84, 497 (2006).

27. C. M. Sena, E. Nunes, T. Louro, T. Proença, R. Fernandes, M. R. Boarder, and R. M. Seiça, Br. J. Pharmacol. 153, 894 (2008). http://dx.doi.org/10.1038/sj.bjp.0707474

28. R. Da. Ros, R. Assaloni, and A. Ceriello. 6, 503 (2005). 